\title{
Outcomes of tuberculosis treatment in a tertiary health facility in north-central Nigeria
}

\author{
${ }^{* 1}$ Audu, E. S., ${ }^{2}$ Adiukwu, C. V., ${ }^{3}$ Dick, S. N., ${ }^{4}$ Bello, S. O., ${ }^{5}$ Aboki, D. M., ${ }^{6}$ Ashuku, Y. A., \\ and ${ }^{7}$ Tomen, E. A.

\begin{abstract}
${ }^{1}$ Special Treatment Clinic, Dalhatu Araf Specialist Hospital, Lafia, Nasarawa State, Nigeria ${ }^{2}$ Department of Internal Medicine, Dalhatu Araf Specialist Hospital, Lafia, Nasarawa State, Nigeria

${ }^{3}$ TB/DOTS Unit, Dalhatu Araf Specialist Hospital, Lafia, Nasarawa State, Nigeria

${ }^{5}$ TBLCP, Nasarawa State Ministry of Health, Nasarawa State, Nigeria

${ }^{6}$ College of Medicine, Federal University Lafia, Nasarawa State, Nigeria

${ }^{7}$ Department of Family Medicine, Dalhatu Araf Specialist Hospital, Lafia, Nasarawa State, Nigeria
\end{abstract} \\ ${ }^{4}$ Department of Paediatrics, Dalhatu Araf Specialist Hospital, Lafia, Nasarawa State, Nigeria \\ *Correspondence to: estanamo@gmail.com;+2347030969315
}

\begin{abstract}
:
Background: Tuberculosis (TB) remains a major public health concern despite being a curable and preventable disease. The treatment of TB using a cocktail of drugs over a period of six months under the directly observed treatment short-course strategy has led to a reduction in cases but is plagued by some challenges that leads to unsuccessful or poor outcomes, which can ultimately result in spread of infections, development of drug resistance and increase in morbidity and mortality. The objectives of this study are to determine outcomes of TB treatment in Dalhatu Araf Specialist Hospital, Lafia, Nasarawa State, Nigeria and the factors that may be associated with the outcomes.

Methodology: This was a retrospective study using the medical records of patients who were registered for TB treatment over a five-year period between 2016 to 2020. Data from TB registers including demographic and relevant clinical information, and treatment outcomes, were extracted into a structured data extraction format, and analysed with SPSS version 21.0 software package. Univariate and bivariate analyses were conducted, and Chi square test was used to determine association between TB outcomes and independent variables at $95 \%$ confidence interval and $p<0.05$ was considered as the significant value.

Results: Records of 1,313 patients were studied, $744(56.7 \%)$ were males while $569(43.3 \%)$ were females. The age range of the patients was $\leq 1$ year - 96 years, with a mean age of $30 \pm 16.7$ years. Most were pulmonary TB cases $(88.8 \%, n=1,166)$, newly diagnosed $(95.5 \%, n=1254)$, and human immunodeficiency virus (HIV) negative at the time of TB diagnosis $(63.7 \%, n=837)$. Eight hundred and seven $(61.5 \%)$ patients had successful treatment, and $34 \%$ $(n=446)$ had unsuccessful outcomes made of 'loss to follow-up' $25.8 \%(n=339)$, deaths $7.8 \%(n=102)$ and treatment failure $0.4 \%(n=5)$, while $2.3 \%(n=30)$ were transferred out and $2.3 \%(n=30)$ removed from TB register. Treatment success rate was significantly higher in patients with pulmonary TB $(p=0.0024)$, residents in Lafia LGA $(p=0.0005)$, those treated in $2016(p=0.0006)$ and bacteriologically confirmed cases $(p<0.0001)$, while death rate was significantly lower among patients who were HIV-negative at the time of TB diagnosis $(p<0.0001)$.

Conclusion: TB treatment success rate in this study fell short of the WHO average rate. High rates of 'loss to followup' and deaths in this study is a wake-up call to all stakeholders in the facility and the State to put in place measures to reduce poor outcomes of TB treatment.
\end{abstract}

Keywords: tuberculosis; treatment outcomes; directly observed treatment short course; factors

Received Jul 10, 2021; Revised Oct 19, 2021; Accepted Oct 20, 2021; Published online Jan 18, 2022

Copyright 2022 AJCEM Open Access. This article is licensed and distributed under the terms of the Creative Commons Attrition 4.0 International License <a rel="license" href="http://creativecommons.org/licenses/by/4.0/", which permits unrestricted use, distribution and reproduction in any medium, provided credit is given to the original author(s) and the source. Editor-in-Chief: Prof. S. S. Taiwo

\section{Résultats du traitement de la tuberculose dans un établissement de santé tertiaire du centre-nord du Nigéria}

\author{
${ }^{* 1}$ Audu, E. S., ${ }^{2}$ Adiukwu, C. V., ${ }^{3}$ Dick, S. N., ${ }^{4}$ Bello, S. O., ${ }^{5}$ Aboki, D. M., ${ }^{6}$ Ashuku, Y. A., \\ et ${ }^{7}$ Tomen, E. A.
}




\author{
${ }^{1}$ Clinique de traitement spécial, Hôpital spécialisé Dalhatu Araf, Lafia, État de Nasarawa, Nigéria \\ ${ }^{2}$ Département de médecine interne, Hôpital spécialisé Dalhatu Araf, Lafia, État de Nasarawa, Nigéria \\ ${ }^{3}$ TB/Unité DOTS, Hôpital spécialisé Dalhatu Araf, Lafia, État de Nasarawa, Nigéria \\ ${ }^{4}$ Département de pédiatrie, Hôpital spécialisé de Dalhatu Araf, Lafia, État de Nasarawa, Nigéria \\ ${ }^{5}$ TBLCP, Ministère de la Santé de l'État de Nasarawa, État de Nasarawa, Nigéria \\ ${ }^{6}$ Collège de médecine, Université fédérale de Lafia, État de Nasarawa, Nigéria \\ ${ }^{7}$ Département de médecine familiale, Hôpital spécialisé de Dalhatu Araf, Lafia, État de Nasarawa, Nigéria \\ *Correspondance à: estanamo@gmail.com; +2347030969315
}

\section{Résumé:}

Contexte: La tuberculose (TB) reste un problème majeur de santé publique bien qu'il s'agisse d'une maladie curable et évitable. Le traitement de la tuberculose à l'aide d'un cocktail de médicaments sur une période de six mois dans le cadre de la stratégie de traitement de courte durée sous observation directe a conduit à une réduction des cas, mais est entravé par certains défis qui conduisent à des résultats infructueux ou médiocres, ce qui peut finalement entraîner propagation des infections, développement de la résistance aux médicaments et augmentation de la morbidité et de la mortalité. Les objectifs de cette étude sont de déterminer les résultats du traitement de la tuberculose à l'hôpital spécialisé Dalhatu Araf, Lafia, État de Nasarawa, Nigéria et les facteurs qui peuvent être associés aux résultats.

Méthodologie: Il s'agissait d'une étude rétrospective utilisant les dossiers médicaux des patients qui ont été enregistrés pour un traitement contre la tuberculose sur une période de cinq ans entre 2016 et 2020 . Les données des registres de la tuberculose, y compris les informations démographiques et cliniques pertinentes, et les résultats du traitement, ont été extraites dans un format d'extraction de données, et analysé avec le progiciel SPSS version 21.0. Des analyses univariées et bivariées ont été menées, et le test du Chi carré a été utilisé pour déterminer l'association entre les résultats de la TB et les variables indépendantes à un intervalle de confiance de $95 \%$ et $p<0,05$ a été considéré comme la valeur significative.

Résultats: Les dossiers de 1313 patients ont été étudiés, 744 (56,7\%) étaient des hommes tandis que 569 (43,3\%) étaient des femmes. La tranche d'âge des patients était $\leq 1$ an - 96 ans, avec un âge moyen de $30 \pm 16,7$ ans. La plupart étaient des cas de TB pulmonaire $(88,8 \%, n=1166)$, nouvellement diagnostiqués $(95,5 \%, n=1254)$ et négatifs pour le virus de l'immunodéficience humaine (VIH) au moment du diagnostic de TB $(63,7 \%, n=837)$. Huit cent sept $(61,5 \%)$ patients ont eu un traitement réussi, et $34 \%(n=446)$ ont eu des résultats infructueux constitués de «perte de suivi» de $25,8 \%(n=339)$, de décès de $7,8 \%(n=102)$ et échec du traitement $0,4 \%(n=5)$, tandis que $2,3 \%(n=30)$ ont été transférés et $2,3 \%(n=30)$ retirés du registre TB. Le taux de réussite du traitement était significativement plus élevé chez les patients atteints de TB pulmonaire $(p=0,0024)$, les résidents de Lafia LGA $(p=0,0005)$, ceux traités en $2016(p=0,0006)$ et les cas confirmés bactériologiquement $(p<0,0001)$, tandis que le taux de mortalité était significativement plus faible chez les patients séronégatifs au moment du diagnostic de TB $(p<0,0001)$.

Conclusion: Le taux de réussite du traitement antituberculeux dans cette étude était inférieur au taux moyen de l'OMS. Les taux élevés de «pertes de vue » et de décès dans cette étude sont un signal d'alarme pour toutes les parties prenantes de l'établissement et de l'État afin de mettre en place des mesures pour réduire les mauvais résultats du traitement de la tuberculose.

Mots-clés: tuberculose; résultats du traitement; traitement de courte durée sous observation directe; facteurs

\section{Introduction:}

Tuberculosis (TB) is a chronic but curable and preventable infection that has remained a major cause of morbidity and mortality in many developing countries of the world (1). Tuberculosis is caused by the bacterium, Mycobacterium tuberculosis, which is spread by infected droplets (1). TB primarily occurs in the lungs but infections can spread outside the lungs, resulting in extra pulmonary infections which can affect any system in the body (1). Everyone who comes in contact with TB infected droplets is at risk of developing the infection but only about $5-10 \%$ of infected people will become ill with the disease (1). Several factors are known to contribute to the risk of active TB disease including conditions which lead to compromised immunity such as human immunodeficiency virus (HIV) infection, diabetes mellitus, and conditions that damage to the lungs such as tobacco smoking (1). TB affects people of all ages with morbidity and mortality higher in those with underlying conditions and compromised immunity such as HIV, malnutrition, and diabetes (1).

The World Health Organization (WHO) reports that all regions of the world are affected by TB. However, 30 countries have been identified as high burden countries for TB, accounting for $87 \%$ of the total global burden of TB in 2019 (1-3). The TB high burden countries are found mostly in Africa and Asia with few in Eastern Europe and the Americas. Nigeria accounts for $4.4 \%$ of the global TB burden (2). An estimated 10 million people were reported to have fallen ill with TB in 2019 (2). Of these, 1.4 million deaths were recorded, $15 \%$ of which occurred in children and about 208,000 in people living with HIV $(2,3)$. People living with HIV (PLHIV) are 18 times more likely to develop TB than those who are HIV negative. The wide availability of anti- 
retroviral drugs (ARVS) and the early commencement of ARVs has led to a decline in morbidity and mortality from TB in people living with HIV (PLHIV) $(4,5)$.

TB is curable with a combination of drugs (6). The WHO global strategy for control of TB involves the use of the Directly Observed Treatment Short course (DOTS) strategy where a provider observes the administration of drugs over a short course of about 6 months (6). Treatments are provided at no cost to the patients in all countries through the WHO global initiative to stop TB supported by various international partners (6). The DOTS strategy in Nigeria was adopted in 2003 and aimed at ensuring adherence to treatment thus reducing the rates of relapse, failure and overall favorable outcomes for the patient and achievement of epidemic control $(6,7)$.

During the course of treatment, different outcomes can occur. These outcomes are influenced by several factors among which include coexisting diseases such as HIV and DM (7). Successful completion of treatment will lead to cure which can be bacteriologically or clinically confirmed whereas those who do not complete treatment can have several unsuccessful outcomes, including loss to follow up, treatment failure and death $(8,9)$. These unsuccessful outcomes ultimately result in morbidity or mortality in the patient as well as unfavorable epidemiologic outcomes resulting in infection spread (8, 9).

Several studies have been conducted on treatment outcomes for TB in different states in Nigeria with different factors identified as contributing to the outcomes $(10,11)$. This current study seeks to have a State and facility specific data to help in fashioning out facility specific interventions to improve TB treatment outcomes for patients accessing treatment in our facility. The overall aim of this study is to assess the treatment outcome of patients treated for TB in Dalhatu Araf Specialist Hospital, Lafia, and the specific objectives are to assess outcome of TB patients who registered for TB treatment in the facility, and identify factors associated with the treatment outcomes.

\section{Materials and method:}

\section{Study area:}

The study was carried out in Dalhatu Araf Specialist Hospital, located in Lafia, Nasarawa State in north-central Nigeria. Lafia is located in Nasarawa South senatorial zone, one of the three senatorial zones of the State. The other senatorial zones are Nasarawa North and West. Other local government areas (LGAs) in
Nasarawa South senatorial zone include Doma, Awe, Keana and Obi. The State is bounded by Benue State in the south, Taraba State in the east, Plateau and Kaduna States in the north and Kogi State and the Federal Capital territory (FCT) in the west. The Dalhatu Araf Specialist hospital is a tertiary health facility located in Lafia, the State capital and offers both tertiary and secondary health services to people from the State and the neighboring States.

\section{Study population and design:}

The study utilized data of patients (both adults and children) who were registered for TB treatment in the TB treatment unit of the facility. The study was a retrospective design utilizing secondary data from TB treatment registers.

\section{Sampling method and selection criteria:}

TB patients who presented for treatment from January 2016 to December 2020 and captured in the TB register, were considered for the study. All TB patients with documented treatment outcomes were included while patients with more than one documented treatment outcomes were excluded

\section{Ethical consideration:}

Approval for the study was obtained from Dalhatu Araf Specialist Hospital (DASH) Research Ethics Committee. Confidentiality of data was ensured as no identifiable information of the patients was collected. Registers were handled carefully and with utmost confidentiality by the researchers during data extraction. All registers were kept in a locked cabinet when not in use. All data were imputed in a password protected personal computer accessible only to the researcher. No consent was sought for the study because there was no contact with patients and extracted patients' data did not carry any identifiers.

\section{Data collection:}

Data were collected from the DOTS TB treatment registers over a five-month period (February-June 2021). The register was developed by the National TB and Leprosy Control program (NTBLCP) of the Nigerian Federal Ministry of Health. Data collected include; (i) demographic variables (age, gender and local govern ment/State of residence); (ii) clinical variables such as site of TB (pulmonary or extra pulmonary); (iii) category of TB (newly diagnosed, relapse, treatment after failure, treatment after 'loss to follow-up'); (iv) methods of TB diagnosis (sputum smear microscopy, GeneXpert, chest radiographs, biopsy, clinical suspicion); (v) HIV serostatus (HIV positive, HIV negative, 
HIV positive on anti-retroviral drugs) and; (vi) treatment outcome variables such as treatment success (cured or completed treatment), treatment failure, death, lost to follow-up, transferred out, removed from the register or not evaluated.

The definition of terms referred to in TB treatment outcomes are; (i) cure, in a TB patient who was bacteriologically (sputum smear) positive at diagnosis and sputum smear negative in the last month of treatment and at least one previous occasion; (ii) treatment completed in a TB patient who completed treatment but did not meet criteria for cure or failure; (iii) treatment success in a TB patient whose outcome was cure or treatment completed; (iv) treatment failure in any TB patient who was smear positive at 5 months or later during treatment; ( $v$ ) death of TB patient from any cause while on TB treatment; (vi) loss to follow-up in TB patient whose treatment was interrupted for 2 or more consecutive months; (vii) transferred out in a TB patient for whose outcome is not known due to transfer to other facility, and therefore not evaluated; (viii) removed from TB register in a patient from whom Mycobacterium tuberculosis was detected with rifampicin (RIF) resistance at any point and were moved to the second line register; and (ix) unsuccessful outcome in those who had treatment failure, lost to follow-up or died.

Data processing and statistical analysis:

Data were analysed with the Statistical Package for Social Sciences (SPSS) version 20.
Analysis was carried out using descriptive and bivariate statistics, and Chi square test was used to determine relationships between variables, with $p$ value $<0.05$ considered statistically significant.

\section{Results:}

A total of 1,313 TB patients were studied, age range $<1$ year-96 years and mean age $30.24 \pm 16.7$ years, with $62 \%(n=814)$ between age $21-50$ years. Children aged $\leq 10$ years constituted $12.3 \%(n=162)$ and $27.5 \%(n=361)$ were $\leq 20$ years old. There were more males $(n=744$, $56.7 \%)$ than females $(n=569,43.3 \%)$ with a male to female ratio of $1.3: 1$. Most $(n=1037$, $79.0 \%$ ) of the study population were resident in Lafia LGA (Table 1).

A total of $1,166(88.8 \%)$ patients had pulmonary tuberculosis (PTB) while 147 (11. 2\%) had extrapulmonary TB, 1254 (95.5\%) were newly diagnosed, and 32 (2.4\%) were relapse cases. Most $(n=820,62.5 \%)$ of the patients were bacteriologically confirmed by sputum smear or GeneXpert at diagnosis, while 484 (36. $7 \%$ ) had their diagnosis by biopsy, radiological or clinical means. Most $(n=837,63.7 \%)$ of the patients were HIV-negative at the time of TB diagnosis (Table 2). A total of 807 (61.5\%) had successful treatment outcome while 446 (34\%) had unsuccessful outcomes such as treatment failed $(0.4 \%, n=5)$, 'loss-to-follow-up' (25.8\% $\mathrm{n}=339)$, death $(7.8 \%, \mathrm{n}=102)$, and $30(2.3 \%)$ patients transferred out while another $30(2.3 \%)$ were removed from the TB register (Table 3 ).

Table 1: Distribution of TB patients by demographic characteristics

\begin{tabular}{ccc}
\hline \multicolumn{1}{c}{ Variable } & Frequency & Percentages \\
\hline Gender & & 56.7 \\
Male & 744 & 43.3 \\
Female & 569 & 100 \\
Total & 1313 & 12.3 \\
Age group category (years) & & 15.2 \\
$1-10$ & 162 & 28.6 \\
$11-20$ & 199 & 23.2 \\
$21-30$ & 376 & 10.2 \\
$31-40$ & 304 & 5.0 \\
$41-50$ & 134 & 3.3 \\
$51-60$ & 66 & 1.7 \\
$61-70$ & 43 & 0.2 \\
$71-80$ & 22 & 100 \\
$81-90$ & 3 & 79 \\
Total & 1313 & 16.6 \\
LGA/State of residence & & 2.4 \\
Lafia LGA in Nasarawa South senatorial zone & 1037 & 1.0 \\
Other LGAs in Nasarawa South & 218 & 1.0 \\
LGAs in Nasarawa North & 31 & 0.1 \\
LGAs in Nasarawa West & 13 & $\mathbf{1 0 0}$ \\
Neighboring States and FCT & 13 & 1 \\
Other States & $\mathbf{1 3 1 3}$ & \\
Total & & \\
\hline
\end{tabular}


Table 2: Distribution of TB patients by clinical characteristics

\begin{tabular}{ccc}
\hline \multicolumn{1}{c}{ Variable } & Frequency & Percentages \\
\hline Site of TB & & 88.8 \\
Pulmonary TB & 1166 & 11.2 \\
Extra pulmonary TB & 147 & 100 \\
Total & 1313 & 95.5 \\
of TB & 1254 & 2.4 \\
Rewly diagnosed & 32 & 0.8 \\
Treatment after failure & 10 & 0.1 \\
Treatment after loss to follow-up & 1 & 0.4 \\
Other previously treated TB patient & 5 & 0.8 \\
Transfer-in & 11 & 100 \\
Total & 1313 & \\
of TB diagnosis & & \\
Bacteriogically Confirmed by sputum smear or Gene Xpert & 820 & 36.9 \\
Retiograph, Biopsy or Clinical & 484 & 0.7 \\
Total unknown & 9 & 100 \\
Pesitive & 1313 & 32.9 \\
Negative & & 63.7 \\
Unknown & 432 & 3.4 \\
Total & 837 & 100 \\
HIV status at time of TB diagnosis & 44 & \\
2016 & 1313 & 20.5 \\
2018 & & 21.8 \\
2019 & 269 & 17.9 \\
2020 & 286 & 25.7
\end{tabular}

Table 3: Distribution of patients by treatment outcomes

\begin{tabular}{ccc}
\hline $\begin{array}{c}\text { Treatment } \\
\text { outcomes }\end{array}$ & Frequency & Percentage \\
\hline $\begin{array}{c}\text { Treatment success } \\
\text { (cured or completed) }\end{array}$ & 807 & 61.5 \\
Treatment failed & 5 & 0.4 \\
Died & 102 & 7.8 \\
Lost to follow-up & 339 & 25.8 \\
Transferred out & 30 & 2.3 \\
Removed from TB & 30 & 2.3 \\
register & $\mathbf{1 3 1 3}$ & $\mathbf{1 0 0}$ \\
Total & & \\
\hline
\end{tabular}

Four hundred and fifty-eight (61.6\%) of 744 males and $349(61.3 \%)$ of 569 females had treatment success, which shows no significant difference between the two genders (OR 1.009, $95 \%$ CI $0.8066-1.263, p=0.9799)$. Treatment success rate was also not significantly associated with age groups of patients $\left(X^{2}=3.617, p=\right.$ $0.0572)$. However, $663(63.9 \%)$ of 1037 resients of Lafia LGA had treatment success, compared to $144(52.2 \%)$ of 276 residents from other LGAs and neighboring States, which shows significantly higher treatment success rate in residents of Lafia LGA (OR 1.625, 95\% CI 1.243$2.125, p=0.0005$ ) (Table 4).
As shown in Table 5, treatment success rate of $62.9 \%(734 / 1166)$ in pulmonary TB patients was significantly higher than success rate of $49.7 \%(73 / 147)$ in extrapulmonary TB cases $(\mathrm{OR}=1.722,95 \% \mathrm{CI}=1.220-2.431, p=$ $0.0024)$. This may be partly accounted for by the significantly lower rates of 'loss to follow up' (LTFU) of $24.3 \%(283 / 1166)$ in pulmonary TB than $38.1 \%(56 / 147)$ in extrapulmonary TB cases $(\mathrm{OR}=0.5208,95 \% \mathrm{CI}=0.3638-0.7457$, $p=0.004)$.

There was no statistically significant difference in the treatment success rate between newly diagnosed TB cases and other TB treatment categories (OR 0.6891, 95\% CI 0.3913-1.215, $p=0.2461)$. Treatment success rate was also not significantly associated with HIV status at the time of diagnosis $\left(X^{2}=4.326, p=0.1150\right)$, however, death rate was significantly higher $\left(X^{2}=\right.$ $39.165, p<0.0001)$ among patients who were HIV positive at the time of TB diagnosis (14.1\%, $61 / 432)$ than those with unknown HIV status $(11.4 \%, 5 / 44)$, and HIV negative patients (4.3\%, $36 / 837)$.

Treatment success rate was significantly higher $\left(X^{2}=19.131, p<0.0001\right)$ in TB cases with bacteriological confirmation of TB at diagnosis 
Table 4: Distribution of TB treatment outcomes of patients by their demographic variables

\begin{tabular}{|c|c|c|c|c|c|c|}
\hline Variable & $\begin{array}{c}\text { Successful } \\
\text { outcome } \\
\text { n }(\%)\end{array}$ & $\begin{array}{c}\text { Treatment } \\
\text { failed } \\
\text { n (\%) }\end{array}$ & $\begin{array}{c}\text { Died } \\
\text { n (\%) }\end{array}$ & $\begin{array}{c}\text { LTFU } \\
\text { n (\%) }\end{array}$ & $\begin{array}{c}\text { T/O } \\
\text { n (\%) }\end{array}$ & $\begin{array}{c}\text { Removed } \\
\text { from } \\
\text { Register } \\
(\text { n \%) } \\
\end{array}$ \\
\hline \multicolumn{7}{|l|}{ Gender } \\
\hline Male $(n=744)$ & $458(61.6)$ & $4(0.5)$ & $51(6.9)$ & $199(26.7)$ & $13(1.7)$ & $19(2.6)$ \\
\hline Female $(n=569)$ & $349(61.3)$ & $1(0.2)$ & $51(8.9)$ & $140(24.6)$ & $17(2.9)$ & $11(1.9)$ \\
\hline Total $(n=1313)$ & 807 (61.5) & $5(0.4)$ & $102(7.8)$ & $339(25.8)$ & $30(2.3)$ & $30(2.3$ \\
\hline OR & 1.009 & 3.070 & 0.7475 & 1.119 & 0.5775 & 1.329 \\
\hline $95 \% \mathrm{CI}$ & $0.8066-1.263$ & $0.3420-27.550$ & $0.4988-1.120$ & $0.8709-1.437$ & $0.2781-1.199$ & $0.627-2.817$ \\
\hline$p$ value & 0.9799 & 0.5466 & 0.1901 & 0.4148 & 0.1922 & 0.5759 \\
\hline \multicolumn{7}{|l|}{ Age group (years) } \\
\hline $1-10(n=162)$ & $87(53.7)$ & 0 & $20(12.3)$ & $49(30.2)$ & $3(1.9)$ & $3(1.9)$ \\
\hline $11-20(n=199)$ & $132(66.3)$ & 0 & $17(8.5)$ & $46(23.1)$ & $2(1.0)$ & $5(2.5)$ \\
\hline $21-30(n=376)$ & 259 (68.9) & $1(0.3)$ & $19(5.1)$ & $85(22.6)$ & $6(1.6)$ & $6(1.6)$ \\
\hline $31-40(n=304)$ & $184(60.5)$ & $2(0.7)$ & $31(10.2)$ & $71(23.4)$ & $8(2.6)$ & $8(2.6)$ \\
\hline $41-50(n=134)$ & $74(55.2)$ & $1(0.7)$ & $6(4.5)$ & $45(33.6)$ & $4(2.9)$ & $4(2.9)$ \\
\hline $51-60(n=66)$ & $31(46.9)$ & 0 & $7(10.6)$ & $24(36.4)$ & $1(1.5)$ & $3(1.9)$ \\
\hline $61-70(n=43)$ & $24(55.8)$ & $1(2.3)$ & $1(2.3)$ & $13(30.2)$ & $3(6.9)$ & $1(2.3)$ \\
\hline $71-80(n=22)$ & $11(50.0)$ & 0 & $2((9.1)$ & $6(27.3)$ & $3(13.6)$ & 0 \\
\hline $81-90(n=3)$ & $2(66.7)$ & 0 & $1(33.3)$ & 0 & 0 & 0 \\
\hline Total $(n=1313)$ & $807(61.5)$ & $5(0.4)$ & $102(7.8)$ & $339(25.8)$ & $30(2.3)$ & $30(2.3)$ \\
\hline$X^{2}($ for trend $)$ & 3.617 & NA & 18.176 & NA & NA & NA \\
\hline$p$ value & 0.0572 & & 0.2965 & & & \\
\hline \multicolumn{7}{|l|}{ LGA/State of residence } \\
\hline Lafia LGA in Nasarawa South $(n=1037)$ & $663(63.9)$ & $3(0.3)$ & $78(7.5)$ & $248(23.9)$ & $19(1.8)$ & $26(2.5)$ \\
\hline Other LGAs in Nasarawa South $(n=218)$ & $121(55.5)$ & $2(0.9)$ & $15(6.9)$ & $71(32.6)$ & $6(2.8)$ & $3(1.4)$ \\
\hline LGAs in Nasarawa North $(n=31)$ & $16(51.6)$ & 0 & $7(22.5)$ & $5(16.1)$ & $3(9.7)$ & 0 \\
\hline LGAs in Nasarawa West $(n=13)$ & $3(23.1)$ & 0 & $1(7.7)$ & $8(61.5)$ & 0 & $1(7.7)$ \\
\hline Neighboring States/FCT $(n=13)$ & $4(30.8)$ & 0 & $1((7.7)$ & $6(46.2)$ & $2(15.4)$ & 0 \\
\hline Other States in Nigeria $(n=1)$ & 0 & 0 & 0 & $1(100)$ & 0 & 0 \\
\hline Total $(n=1313)$ & $807(61.5)$ & $5(0.4)$ & $102(7.8)$ & $339(25.8)$ & $30(2.3)$ & $30(2.3)$ \\
\hline $\mathrm{OR}^{+}$ & 1.625 & 0.3975 & 0.8540 & 0.6390 & 0.4496 & 1.749 \\
\hline $95 \% \mathrm{CI}^{+}$ & $1.243-2.125$ & $0.06606-2.392$ & $0.5294-1.378$ & $0.4787-0.8529$ & $0.2113-0.9566$ & $0.605-5.055$ \\
\hline$p$ value $^{+}$ & $0.0005^{*}$ & 0.6215 & 0.6024 & $0.0029 *$ & 0.0573 & 0.4129 \\
\hline
\end{tabular}

$(65.9 \%, 541 / 820)$ than those with clinical/ radiological diagnosis $(54.1 \%, 262 / 484)$ and unknown method of diagnosis $(55.6 \%, 4 / 9)$. This observation may be partly due to the lower rate of 'lost to follow up' (LTFU) of $22.5 \%$ $(187 / 820)$ in those with bacteriological confirmation compared to $30.6 \%(148 / 484)$ in those with clinical/radiological diagnosis and $55.6 \%$ (4/9) in those with unknown method of diagnosis $\left(X^{2}=11.244, p=0.0036\right)$. Treatment success rate was significantly higher in 2016 $(71.4 \%, 192 / 269)$ than the other years $\left(X^{2}=\right.$ $19.522, p=0.0006)$, which may partly be due to the fact that 'loss to follow up' (LTFU) rate was significantly lower in $2016(17.8 \%, 48 / 269)$ than the other years $\left(X^{2}=26.660, p<0.0001\right)$.

\section{Discussion:}

The introduction of DOTS for TB treatment was a novel strategy that improved the overall outcomes for patients treated for TB especially in developing countries $(7,8)$. However, the DOTS strategy is being challenged by many issues such as poor adherence, treatment default and failure $(7,8)$. In this study, the finding of treatment success rate of $61.5 \%$ in the TB patients on treatment is similar to the report from another facility in north-central Nigeria which reported $67 \%$ of TB patients had successful treatment outcomes (10). Similar findings were also reported in other studies from East Africa with rates of successful treatment outcomes between $60 \%$ and $67 \%(12,13)$. This similarity in findings may be due to the fact that these studies are all from developing countries with similar socioeconomic characteristics. Many studies from Africa however reported lower rates of treatment success from $25 \%$ to $56 \%$ (14-16). The low treatment success rate in one study was due to a high rate of transfer out of over $60 \%$ to other facilities as reported by Biadglegne et al., in 2013 (14).

Our finding of $61.5 \%$ treatment success rate is however still lower than the rates reported in studies from other regions of the world including Asia and Europe with over $70 \%$ of TB patients having successful treatment outcomes (16-18). Higher rates of treatment success in developed nations of Europe and Asia may be due to more advanced health care services than obtained in the developing and often resource poor countries of Africa including Nigeria. The 
Table 5: TB treatment outcomes of patients in relation to clinical variables

\begin{tabular}{|c|c|c|c|c|c|c|}
\hline Variable & $\begin{array}{c}\text { Successful } \\
\text { treatment } \\
\mathrm{n}(\%)\end{array}$ & $\begin{array}{l}\text { Treatment } \\
\text { failed } \\
\text { n (\%) } \\
\end{array}$ & $\begin{array}{l}\text { Died } \\
\text { n (\%) }\end{array}$ & $\begin{array}{l}\text { LTFU } \\
\text { n (\%) }\end{array}$ & $\begin{array}{c}\mathrm{T} / \mathrm{O} \\
\mathrm{n}(\%)\end{array}$ & $\begin{array}{c}\text { Removed from } \\
\text { Register } \\
\text { n (\%) }\end{array}$ \\
\hline \multicolumn{7}{|l|}{ Site of TB } \\
\hline Pulmonary TB $(n=1166)$ & $734(62.9)$ & $4(0.3)$ & $91(7.8)$ & $283(24.3)$ & $27(2.3)$ & $27(2.3)$ \\
\hline Extra pulmonary TB $(n=147)$ & 73 (49.7) & $1(0.7)$ & $11(7.5)$ & $56(38.1)$ & $3(2.0)$ & $3(2.0)$ \\
\hline Total $(n=1313)$ & $807(61.5)$ & $5(0.4)$ & $102(7.8)$ & $339(25.8)$ & $30(2.3)$ & $30(2.3)$ \\
\hline OR & 1.722 & 0.5026 & 1.047 & 0.5208 & 1.138 & 1.138 \\
\hline $95 \% \mathrm{CI}$ & $1.220-2.431$ & $0.05577-4.529$ & $0.5460-2.006$ & $0.3638-0.7457$ & $0.3408-3.799$ & $0.340-3.799$ \\
\hline$p$ value & $0.0024^{*}$ & 0.5316 & 0.8909 & $0.004 *$ & 0.8336 & 0.8336 \\
\hline \multicolumn{7}{|l|}{ TB treatment category } \\
\hline Newly diagnosed $(n=1254)$ & $766(61.1)$ & $4(0.3)$ & $100(7.9)$ & $326(25.9)$ & $29(2.3)$ & $27(2.2)$ \\
\hline Relapse $(n=32)$ & $23(71.9)$ & 0 & 0 & $7(21.9)$ & $1(3.1)$ & $3(9.4)$ \\
\hline Treatment after failure $(n=10)$ & $6(60.0)$ & $1(10.0)$ & $1(10.0)$ & $2(20.0)$ & 0 & 0 \\
\hline $\begin{array}{l}\text { Treatment after loss to follow up } \\
(n=1)\end{array}$ & 0 & 0 & $1(100)$ & 0 & 0 & 0 \\
\hline $\begin{array}{l}\text { Other previously treated TB patient } \\
(n=5)\end{array}$ & $5(100)$ & 0 & 0 & 0 & 0 & 0 \\
\hline Transfer-in $(n=11)$ & $7(63.6)$ & 0 & 0 & $4(36.4)$ & 0 & 0 \\
\hline Total $(n=1313)$ & $807(61.5)$ & $5(0.4)$ & $102(7.8)$ & $339(25.9)$ & $30(2.3)$ & $30(2.3)$ \\
\hline $\mathrm{OR}^{+}$ & 0.6891 & 0.1856 & 2.470 & 1.243 & 1.373 & 0.4108 \\
\hline $95 \% \mathrm{CI}^{+}$ & $0.3913-1.213$ & $0.02041-1.688$ & $0.5939-10.269$ & $0.6630-2.331$ & $0.1837-10.261$ & $0.120-1.395$ \\
\hline$p$ value $^{+}$ & 0.2461 & 0.5515 & 0.2998 & 0.5978 & 0.7563 & 0.3044 \\
\hline \multicolumn{7}{|l|}{ Method of TB diagnosis } \\
\hline $\begin{array}{l}\text { Bacteriologically confirmed by } \\
\text { sputum smear or Gene Xpert } \\
(n=820)\end{array}$ & $541(65.9)$ & $5(0.6)$ & $46(5.6)$ & $187(22.8)$ & $20(2.4)$ & $21(2.6)$ \\
\hline $\begin{array}{l}\text { Radiologic, Biopsy or Clinical } \\
(n=484)\end{array}$ & $262(54.1)$ & 0 & $56(11.6)$ & $148(30.6)$ & $10(2.0)$ & $8(1.7)$ \\
\hline $\begin{array}{l}\text { Method of diagnosis not recorded } \\
(n=9)\end{array}$ & $4(55.6)$ & 0 & 0 & $4(55.6)$ & 0 & $1(11.1)$ \\
\hline Total $(n=1313)$ & $807(61.5)$ & $5(0.4)$ & $102(7.8)$ & $339(25.9)$ & $30(2.3)$ & $30(2.3)$ \\
\hline$x^{2}$ & 19.131 & NA & NA & 11.244 & NA & 4.286 \\
\hline$p$ value & $<0.0001 *$ & & & $0.0036 *$ & & 0.1173 \\
\hline \multicolumn{7}{|l|}{ HIV status at time of TB diagnosis } \\
\hline Positive $(n=432)$ & $249(57.6)$ & 0 & $61(14.1)$ & $107(24.8)$ & $9(2.1)$ & $6(1.4)$ \\
\hline Negative $(n=837)$ & $532(63.6)$ & $5(0.6)$ & $36(4.3)$ & $222(26.5)$ & $21(2.5)$ & $21(2.5)$ \\
\hline Unknown $(n=44)$ & $26(59.1)$ & 0 & $5(11.4)$ & $10(22.7)$ & 0 & $3(6.8)$ \\
\hline Total $(n=1313)$ & $807(61.5)$ & $5(0.4)$ & $102(7.8)$ & 339 (25.9) & $30(2.3)$ & $30(2.3)$ \\
\hline$x^{2}$ & 4.326 & NA & 39.165 & 0.6853 & NA & 5.792 \\
\hline$p$ value & 0.1150 & & $<0.0001 *$ & 0.7099 & & 0.0553 \\
\hline \multicolumn{7}{|c|}{ Year patient was registered for TB treatment } \\
\hline $2016(n=269)$ & $192(71.4)$ & $2(0.7)$ & $22(8.2)$ & $48(17.8)$ & $5(1.9)$ & 0 \\
\hline $2017(n=286)$ & $180(62.9)$ & 0 & $24(8.4)$ & $72(25.2)$ & $4(1.4)$ & $6(2.1)$ \\
\hline $2018(n=235)$ & $135(57.4)$ & $1(0.4)$ & $20(8.5)$ & $55(23.4)$ & $12(5.1)$ & $12(5.1)$ \\
\hline $2019(n=338)$ & $185(54.7)$ & $2(0.6)$ & $18(5.3)$ & $120(35.5)$ & $3(0.9)$ & $10(2.9)$ \\
\hline $2020(n=185)$ & $115(62.2)$ & 0 & $18(9.7)$ & $44(23.8)$ & $6(3.2)$ & $2(1.1)$ \\
\hline Total $(n=1313)$ & $807(61.5)$ & $5(0.4)$ & $102(7.8)$ & $339(25.9)$ & $30(2.3)$ & $30(2.3)$ \\
\hline$x^{2}$ & 19.522 & NA & 4.207 & 26.660 & 13.321 & NA \\
\hline$p$ value & $0.0006 *$ & & 0.3787 & $<0.0001 *$ & $0.0098 *$ & \\
\hline
\end{tabular}

$\mathrm{n}=$ Frequency; $\%=$ percentage; $\mathrm{LFTU}=$ Lost to follow up; $\mathrm{T} / \mathrm{O}=$ Transferred Out; OR = Odds Ratio; $\mathrm{CI}=$ Confidence Interval; $X^{2}=$ Chi square;

${ }^{*}=$ statistically significant at $p<0.05 ;^{+}=$bivariate analysis was performed by comparing newly diagnosed TB with other TB treatment categories merged together; $\mathrm{NA}=$ not applicable (analysis not possible due to value of zero in some cells)

average Nigerian national TB treatment success rate was reported to be about $86 \%$ in 2016 (7). The lower rate of treatment success in our study may be due to our facility being a referral center with patients being referred from primary and secondary facilities, often with severe illness for diagnosis and once diagnosis is made and patients are discharged from care, they return to the facilities they were referred from.

This study found that patients who defaulted their treatment or were lost to followup $(25.8 \%)$ constituted majority of those with unsuccessful outcomes. This rate is slightly higher than the rates reported from some studies from Nigeria including one from the same region as ours where the default rate was $17 \%-18.5 \%$ $(10,16)$. Similarly, studies elsewhere in Africa reported even lower rates of loss to follow-up $(12,19)$. The loss to follow-up in our study may be due to our facility being a referral center, thus, patients tend to return to their referred facilities and places of residence often without appropriate documentation. The low transfer out rate of $2.3 \%$ in our study may be a further testament to this. The high rate of death (7.8\%) among TB patients in our study is similar to the report of a study from Jos, northcentral Nigeria (10), but lower than the death rates reported in studies from southern Nigeria by Bamidele et al., (11) and Umeokonkwo et al., (16). How- 
ever, the rate in our study is higher than those reported from other regions of Africa and Europe $(12,17)$. Many patients who are referred from primary and secondary healthcare facilities to our center for diagnosis and treatment are in most cases severely ill and present late, which may thus contribute to the high death rate reported in our study. A low treatment failure rate of $0.4 \%$ in our study is similar to rates from other studies in Africa $(12,14)$.

Our study found that both genders had similar treatment outcomes, which contrast with most reports, where males were more likely to have poorer treatment outcomes $(12,15,18)$. However, the study by Gertie and Alemnew (20) in 2020, reported that females had poorer outcomes than males. Although, treatment success rate appeared higher in the age groups 11-20 years $(66.3 \%), 21-30$ years $(68.9 \%)$ and $81-90$ years $(66.7 \%)$, compared to other age groups in our study, the statistical analysis using Chisquare by trend did not show significant difference between the age groups with respect to treatment success $\left(X^{2}=3.617, p=0.0572\right)$ or deaths $\left(X^{2}=18.176, p=0.2965\right)$. This contrasts the findings from other studies that reported poorer outcomes in older age groups $(15,19)$.

Treatment success rate was higher in pulmonary TB cases, those with bacteriological confirmation of TB at diagnosis, and cases resident in Lafia LGA, which may partly be as a result of the significantly lower rates of 'lost to follow up' (LTFU) in these categories of TB patients. However, we did not observe any significant difference in the outcome between newly diagnosed TB and other TB treatment categories (OR 0.6891, 95\% CI 0.3913-1.215, $p=0.2461$ ). HIV positivity at the time of TB diagnosis is a known factor associated with poor TB treatment outcome, but treatment success in our study was not significantly associated with HIV status at the time of TB diagnosis, however, independently, death rate was significantly higher in TB patients who were HIV positive at the time of diagnosis, which agrees with study reports from Africa, Asia and Europe of high mortality associated with TB-HIV co-infections $(12,13,15,20)$.

Overall, this study found significantly higher treatment success rate, and lower rates of loss to follow up and deaths in patients with pulmonary TB, residents in Lafia LGA, patients treated in 2016, patients bacteriologically confirmed, and patients who were HIV-negative at the time of diagnosis, which agrees with many other studies that have reported similar signi- ficant associations of some of these variables with TB treatment success outcome $(10,13,18$, 20).

\section{Conclusion:}

The finding of treatment success rate of $61.5 \%$ among TB patients in our facility falls below the national and WHO average figure. This finding together with the high rates of loss to follow up and death, is a wake-up call to all stakeholders in our facility and the State to put in place necessary measures to reduce these poor outcomes of DOTS TB treatment strategy.

\section{Acknowledgements:}

We wish to acknowledge the staff of the TB/DOTS treatment unit of Dalhatu Araf Specialist Hospital, Lafia. We acknowledge specially Mr. Danjuma Usman for ensuring meticulous record keeping and storage of data tools which made data easy to retrieve.

\section{Funding:}

Authors did not receive any fund/grant

\section{Conflicts of interest:}

Authors declare no conflicts of interest

\section{References:}

1. Tuberculosis. Fact sheets. https://www.who.int.news-room/factsheets/detail (Accessed 02/03/2021)

2. Global tuberculosis report 2020. World Health Organization:2020.

https://www.who.int/publications/i/item/97890013 131 (Accessed 02/03/2021)

3. TB statistics-2019.

https://www.tbfacts.org/tbstatistics/

(Accessed 02/03 2021)

4. Tuberculosis and HIV. WHO.

https://www.who.int>tb-hiv. Accessed 06/03/2021

5. Schulz, C., Meintjes, F., Almajid, F., Wilkinson, J., and Pozniac, A. Clinical management of tuberculosis and HIV-1 co-infection. Euro Respir J. 2010; 36: 1460 - 1481. doi: $10.1183 / 0903136.00110210$.

6. Promoting adherence to treatment for tuberculosis: the importance of direct observation.

https://apps.who.int//iris/handle/10665/270057 (Accessed 05/03/2021)

7. TB in Nigeria- funding, children, diagnosing TB, HIV/TB. https://tbfacts.org/tb-nigeria/ (Accessed 13/03/2021)

8. WHO consolidated guidelines on tuberculosis. https://www.who.int/publications-detailredirect/9789240001503 (Accessed 009/03/2021)

9. Treatment for TB Disease https://www.cdc.gov/tb/topic/treatment/tbdisease .htm (Accessed 05/06/2021)

10. Sariem, C. M., Odumosu, P., Dapar, M. P., et al. Tuberculosis treatment outcomes: a fifteen-year retrospective study in Jos North and Mangu, Plateau State, North Central Nigeria. BMC Publ HIth. 2020; 
20:12-24.https://doi.org/10.1186/s12889-020092 86

11. Babatunde, A. O., Elegbede, O. E., Ayodele, M., et al. Factors affecting Treatment outcomes of Tuberculosis in a Tertiary Health center in South Western Nigeria. Int Rev Soc Sc Humanities. 2013; $4(2): 209-218$.

12. Jemal, M., Tarekegne, D., Ebabu, E., et al. Treatment outcomes of tuberculosis patients in Metema hospital, Northwest Ethiopia: a four-year retrospective study. Mycobact Dis. 2015; 5: 5. http://dx.doi.org/10.4172/2161-1068.1000190

13. Biruk, M., Yiman, B., Abrha, H., Biruk, S., and Andie, F. Z. Treatment outcomes of tuberculosis and Associated factors in an Ethiopian University Hospital. Adv Pub HIth. 2016; Article ID 8504629. http://dx.doi.org/10.1155/2016/8504629

14. Biadgleme, F., Anagaw, B., Debebe, T., et al. A retrospective study on the outcomes of tuberculosis treatment in Felege Hiwot Referral hospital, Northwest Ethiopia. Int J Med Med Sci. 2013; 5 (2) 85-91. doi: 10.5897/IJMMS12.142

15. Tafess, K., Beyen, T. K., Abera, A., et al. Treatment outcomes of Tuberculosis at Asella teaching Hospital, Ethiopia: ten years retrospective aggregated data. Front Med. 2018; 5: 38. https://doi.org/10.3389/fmed.2018.00038
16. Umeokonkwo, C. D., Okedo-Alex, I. N., Azuogu, B. N., Utulun, R., Adeke, A. S., and Disu, Y. O. Trends and determinants of tuberculosis treatment outcomes in a tertiary hospital in Southeast Nigeria. J Infect Pub Hlth. 2020; 13 (7): 1029-1033 https://doi.org/101016/j.jiph:2019.10.012

17. Faustani, A., Hall, A. J., and Perucci, C. A. Tuberculosis treatment outcomes in Europe: a systemic review. Euro Res J. 2005; 26: 503-510. doi:10.1183/09031936.05.00103504

18. Ditah, I. C., Reacher, M., Palmer, C., et al. Monitoring tuberculosis treatment outcome: analysis of National surveillance data from a clinical perspective. Thorax. 2008; 63: 440-446. http://dx.doi.org/10.1136/thx.2006.073916

19. Wen, Y., Zhang, Z., Li, X. et al. Treatment outcomes and factors affecting unsuccessful outcome among new pulmonary smear positive and negative tuberculosis patients in Anging, China: a retrospective study. BMC Inf Dis. 2018; 18: 104 https://doi.org/10.1186/s12879-3019-7

20. Getie, A, and Alemnew, B. Tuberculosis treatment outcome and Associated factors among patients treated at Woldia General Hospital in Northeast Ethiopia: An Institution-based cross-sectional study. Infect Drug Resist 2020: 13. 3423 - 3429 https://doi.org/10.2147/IDR.s275568 